\title{
Clostridium rectum
}

National Cancer Institute

\section{Source}

National Cancer Institute. Clostridium rectum. NCI Thesaurus. Code C86291.

A species of anaerobic, Gram positive, rod shaped bacteria assigned to the phylum

Firmicutes. This species can degrade lindane, a scabicide. 